\title{
The effect of milk fat replacement and the addition of Lactobacillus paracasei LPC-37 on the sensory properties of cheeses
}

\author{
Marika Bielecka*, Grażyna Cichosz

\begin{abstract}
University of Warmia and Mazury, Faculty of Food Science, Department of Dairy Science and Quality Management, Oczapowskiego 7, 10-719 Olsztyn, Poland

*Corresponding author: marika.kowalska@uwm.edu.pl: Tel.: +48 895245179
\end{abstract}

\section{Abstract}

The market of ripened cheese is growing rapidly and is highly competitive. Dairy manufacturers have expanded their product range to include cheese-like products where milk fat is replaced with vegetable oils. Cheese-like products have gained popularity among both convenient food producers and consumers looking for cheaper cheese substitutes. Fat determines the sensory attributes of cheeses. The sensory quality of cheese can also be modified through the addition of selected adjunct cultures. This study evaluated the influence of milk fat replacement with palm oil and the addition of an adjunct culture of Lactobacillus paracasei LPC-37 on the sensory attributes of Dutch-type cheeses and cheese-like products during ripening. The chemical composition, content of volatile compounds and colour were analysed. The replacement of milk fat with palm oil contributed to differences in the sensory profile and colour of cheese-like products and deteriorated their sensory quality. However, the addition of $L$. paracasei LPC-37 improved the sensory characteristics of cheese-like products.

\section{Key words: Lactobacillus paracasei LPC-37, cheese, palm oil, flavour, colour}

\section{Introduction}

Consumers select cheese based on their sensory attributes which incorporate various parameters, including texture, colour, eye formation and, above all, odour and taste (Cakir and Clark, 2009). Non-starter lactic acid bacteria (NSLAB) exert a great influence on the sensory properties of cheese (Cichosz et al., 2006a; Beresford and Williams, 2004). Non-starter lactic acid bacteria cannot be eliminated from cheese. After cheese pressing, NSLAB counts are relatively low, but a 4-5 log in- crease is noted during cheese ripening, depending on the type of cheese. Excessive counts and diversity of NSLAB in cheese can compromise the sensory quality and storage stability of cheese.

The growth and diversity of NSLAB can be limited through the addition of selected adjunct cultures to boost the activity of starter cultures (Settanni and Moschetti, 2010; Broadbanet et al., 2003). Adjunct cultures support the standardization or modification of quality parameters, and they can shorten ripening time (Antonsson et al., 2002; Courtin et al., 2002). The effects of adjunct 
cultures have been extensively researched in different cheese types (Lynch et al., 1996; Antonsson et al., 2002, 2003; Gomez-Ruiz et al., 2008).

Fat and the products of fat hydrolysis are the key determinants of cheese odour and aroma. Enzymatic hydrolysis of triacyloglycerols leads to the production of medium-chain fatty acids (MCFAs) and short-chain fatty acids (SCFAs). The lipolytic and esterolytic activity of microflora is limited, but numerous aroma compounds are formed during long-term ripening. Fat also acts as a solvent and a carrier of aromatic substances released during the degradation of proteins and lactose.

In contrast to cheese, cheese-like products are manufactured from skimmed milk and vegetable oils with or without the addition of milk fat. The replacement of milk fat with vegetable oils affects sensory attributes because fat is a component of the cheese matrix, and it acts as a "filler" that determines the rheological properties of cheese. The replacement of milk fat with vegetable oils also changes the type and distribution of fat globules in the protein matrix, which alters the sensory attributes of the final products (Lobato-Calleros et al., 2002; 2003). Cheeses where milk fat is replaced with vegetable oils are characterized by a more compact network. Vegetable oils are composed of smaller and more homogeneous fat globules (Dinkçi et al., 2011). According to Everett and Auty (2008), homogenization of milk with vegetable oil promotes the formation of smaller and more evenly distributed fat globules. Fat and the products of fat hydrolysis significantly influence the sensory quality of cheese and cheese-like products by determining their consistency, colour and palatability.

\section{Materials and methods}

\section{Cheese production}

Semi-hard ripened cheeses and cheese-like products were investigated. The analysed cheeses were produced under industrial conditions in a dairy cooperative in Giżycko, Poland. Control (2 batches) and experimental ( 2 batches) cheeses were made using 10,000 liters of thermized milk $\left(65^{\circ} \mathrm{C}\right.$ for 15 s) each. After cooling to $4^{\circ} \mathrm{C}$, milk was bactofugated, pasteurized $\left(72^{\circ} \mathrm{C}\right.$ for $\left.15 \mathrm{~s}\right)$, standardized to
$3.0 \%$ fat content and supplemented with $3 \mathrm{~kg}$ of $\mathrm{CaCl}_{2}$ and $110 \mathrm{~mL}$ of Annato colouring agent (Chr Hansen, Poland). Pasteurized milk was inoculated with the Choozit ${ }^{\mathrm{TM}}$ Classic 111 (0.06 \%) (DuPont, Poland) cheese starter culture to produce control cheeses, and it was additionally supplemented with a commercial direct-to-vat-culture of Lactobacillus paracasei LPC-37 (DuPont, Poland) (0.028 \% by volume) to produce experimental cheeses. The CHY-MAX (Chr Hansen, Poland) coagulant enzyme (1:26500) was added in the amount of $450 \mathrm{~mL}$. After approximately 30 minutes, curd was slowly cut with rotating cutting blade frames into 6-8 mm particles. Whey (2500 L) was strained and process water (1300 L) was added. Curds were heated to $39{ }^{\circ} \mathrm{C}$ and pressed. Cheese blocks of $3 \mathrm{~kg}$ were salted for 24 h at $12{ }^{\circ} \mathrm{C}$ in brine $(17 \% \mathrm{w} / \mathrm{v} \mathrm{NaCl})$, hermetically sealed in Cryovac ${ }^{\oplus}$ oxygen barrier bags (Sealed Air, Poland) and ripened at $12{ }^{\circ} \mathrm{C}$ and $85 \%$ humidity for 10 weeks.

In the cheese-like products, milk fat was completely replaced with palm oil (Kruszwica, Poland), and the production process was identical to that of ripened cheese.

After 4, 6 and 10 weeks of ripening, cheese and cheese-like products were subjected to instrumental analyses (volatile free fatty acids and colour) and a sensory evaluation.

\section{Analysis of free short-chain fatty acids}

Ground samples of $6 \mathrm{~g}$ of ripened cheese or cheese-like product were placed into a $22 \mathrm{~mL}$ clear glass crimp vials (Agilent Technologies) and subjected to headspace solid-phase microextraction gas chromatography (HS-SPME-GC). The vials were sealed with $20 \mathrm{~mm}$ aluminum crimp caps with PTFE/silicone septa (Agilent Technologies). Carboxen-polydimethylsiloxane fibre with a thickness of $75 \mu \mathrm{m}$ was used (Supelco, USA, Bellefonte). Equilibrium was achieved after 40 minutes at a temperature of $60^{\circ} \mathrm{C}$. The analyts were desorbed in the injector at $250{ }^{\circ} \mathrm{C}$ in 4 minutes.

Volatile compounds were analysed in the Agilent 7820A GC chromatograph with a flame ionization detector (FID) and a $0.75 \mathrm{~mm}$ ID Straight Ultra Inert Liner for SPME (Agilent Technologies). The sample was introduced in the splitless mode. Chromatographic separation was performed on 
the HP-INNOWax column $(30 \mathrm{~m} \times 0.25 \mathrm{~mm} \times 0.20$ $\mu m)$ (Agilent Technologies, Poland, Warszawa). For gas chromatography, oven temperature was maintained at $40{ }^{\circ} \mathrm{C}$ for 3 minutes, raised to $100{ }^{\circ} \mathrm{C}$ in steps of $5{ }^{\circ} \mathrm{C} \mathrm{min}^{-1}$, maintained at $100^{\circ} \mathrm{C}$ for $2 \mathrm{~min}$, raised to $240{ }^{\circ} \mathrm{C}$ in steps of $10^{\circ} \mathrm{C} \mathrm{min}-1$, and maintained at $240{ }^{\circ} \mathrm{C}$ for 2 min (carrier gas: helium at $0.5 \mathrm{~mL} \mathrm{~min}^{-1}$ for $10 \mathrm{~min}$, raised to $2.5 \mathrm{~mL} \mathrm{~min}^{-1}$ in steps of $0.5 \mathrm{~mL} \mathrm{~min}^{-1}$ ). Injector and detector temperature was set to $250^{\circ} \mathrm{C}$. In a quantitative analysis, volatile free fatty acids were calibrated with external standards (Sigma Aldrich, Poland, Poznan). Peaks were integrated in the ChemStation program (Agilent Technologies, Poland, Warszawa) and identified by comparing analyte retention times in the sample with the retention times of the standards.

\section{Instrumental colouranalysis}

The colour of cheeses and cheese-like products was analysed with the CM-3500d spectrophotometer (Konica Minolta Sensing, Inc. Osaka, Japan) which measures colour transmittance and reflection. Measurements were performed with $d / 8$ geometry, $8 \mathrm{~mm}$ aperture size, $10^{\circ}$ observer angle and D65 illuminant. Before analysis, the device was calibrated against a white calibration plate (CM A120) and a black calibration plate (CM A124). A representative sample was prepared at room temperature immediately before analysis and placed into a CM A-128 Petri dish ( $h=25 \mathrm{~mm}, \varnothing=34$ $\mathrm{mm})$. Colour measurements were conducted in 4 replications.

Colour lightness was calculated in the CIE LAB colour space and expressed by component $L^{*}\left(L^{*}=0\right.$ for black and $L^{*}=100$ for white colour). Chromaticity of the light source was described with components $a^{*}\left(-a^{*}=\right.$ greenness and $+a^{*}=$ redness $)$ and $b^{*}$ $\left(-b^{*}=\right.$ blueness and $+b^{*}=$ yellowness $)$. The values of $L^{*}, a^{*}$ and $b^{*}$ were used to calculate saturation $C^{*}$ and hue angle $H^{*}$ (Ramirez-Navas and de Stouvenel, 2012). Hue was expressed in degrees $\left(H^{*}=0\right.$ for red, $H^{*}=90$ for yellow, $H^{*}=180$ for green, $H^{*}=270$ for blue). The whiteness index (WI) and the yellowness index (YI) were calculated. The colourof cheeses and cheese-like products was evaluated after 4, 6 and 10 weeks of ripening.

\section{Sensory analysis}

\section{Preparation of samples for a sensory analysis}

Cheese and cheese-like products with different degrees of ripeness (after 4, 6 and 10 weeks) were subjected to a sensory analysis. The samples were prepared in a special compartment. Representative cheese cubes were cut into 6 cuboids. The samples were labelled with a three-digit codes and were evaluated by a trained sensory panel.

\section{Sensory evaluation}

Panelists trained in sensory assessment were recruited and screened according to ISO 8586:2012. The sensory trial was conducted in a special test room designed according to ISO 8589:2007. A rating scale was developed for evaluating the samples based on selected attributes according to ISO 4121: 2003. Samples of ripened cheeses and cheese-like products were evaluated based on the following sensory attributes: colour, eye formation, consistency, odour and taste. Based on the quality attributes that are considered most important by consumers, weighting factors of $0.15,0.15,0.20$, 0.25 and 0.25 were adopted for colour, eye formation, consistency, flavour and aroma, respectively, as described by Cichosz et al. (2003).

The samples were evaluated on a six-point scale where each point was defined. The sensory quality of Dutch-type ripened cheeses and cheeselike products was determined according to ISO 22935-3:2009.

\section{Statistical analysis}

The results were analysed statistically by calculating mean value and standard deviation. Differences were determined by factorial analysis of variance test (ANOVA) at a $p<0.05$ significance level. The Tukey test was used for post-hoc analysis. Statistical correlations between colour attributes and ripening time were assessed by the Spearman's rank correlation coefficient. Data were processed in the Statistica v. 10 program (Statsoft, Poland). 


\section{Results and discussion}

The production of ripened cheeses with identical chemical composition is practically impossible, even when the composition of milk is standardized by ultrafiltration and when cheese blocks are formed automatically (Aljewicz et al., 2014). The chemical composition of cheese is determined by the rate of lactose fermentation, curd decalcification and treatments (rinsing grains, cheese salting in brine) which decrease the products' acidity and increase their water content. For these reasons, minor differences in chemical composition cannot be avoided.

The use of L. paracasei LPC-37 as an adjunct culture in the production of Dutch-type cheeses did not influence their chemical composition. The replacement of milk fat with palm oil led to a significant decrease in the fat content of cheese-like products. Therefore, the chemical composition of cheese-like products containing L. paracasei LPC37 as the adjunct culture differed significantly from that of control products (Table 1).

The use of $L$. paracasei LPC-37 as the adjunct culture in the production of Dutch-type cheeses and cheese-like products increased the content of volatile free fatty acids (FFAs) (Table 2). Dutch-type cheeses should be characterised by a relatively limited extent of lipolysis, and the total content of FFAs in cheeses manufactured from pasteurized milk is generally low. However, even low concentrations of short chain FFAs influence the aroma of Gouda cheese, whereas long-chain FFAs can impart an unpleasant soapy flavour to cheese (Dustrerhoft and van den Berg, 2007).

Acetic acid was the predominant volatile carboxylic acid in the analysed products. The content of acetic acid was higher in experimental cheeses and cheese-like products than in control products (Table 2). The presence of acetic acid can be attributed to the activity of both starter cultures and NSLAB (Akın et al., 2003). Heterofermentative strains of $L$. casei are capable of producing lactic acid (Limsowtin et al., 2003). Acetic acid is produced from amino acids, lactose and citric acid, which are fermented by starter cultures and degraded by LAB (Tungjaroenchai et al., 2004). Acetic acid is synthesized during glycolytic processes and the breakdown of amino acids, but its content is also influenced by $\beta$-oxidation of free fatty acids whose chains are shortened by two carbon atoms (Zaręba et al., 2008). A predominance of acetic acid (up to 3500 ppm) was also reported in Edam cheeses produced with the use of Lactococcus lactis subsp. diacetylactis, Brevibacterium linens BL2, Lactobacillus helveticus LH212 and Lactobacillus reuteri ATCC 23272 cultures (Tungjaroenchai et al., 2004).

In the present study, Dutch-type cheeses were characterised by a high content of butyric acid due to the relatively low microbiological quality of milk (unpublished data) produced in March and April. Microbiological and biochemical changes in the examined cheese samples were also intensified by high water content (Table 1). Butyric acid is produced

TABLE 1. Composition of control and experimental Dutch-type cheeses and cheese-like products

\begin{tabular}{|c|c|c|c|c|c|c|c|c|c|c|c|c|c|}
\hline \multirow{3}{*}{$\begin{array}{l}\text { Composition } \\
\text { w/w\% }\end{array}$} & \multirow{3}{*}{ Abbreviation } & \multicolumn{6}{|c|}{ Cheeses } & \multicolumn{6}{|c|}{ Cheese-like products } \\
\hline & & \multicolumn{3}{|c|}{ control } & \multicolumn{3}{|c|}{ experimental } & \multicolumn{3}{|c|}{ control } & \multicolumn{3}{|c|}{ experimental } \\
\hline & & $42.2^{\mathrm{a}}$ & \pm & 0.2 & $42.4^{a}$ & \pm & 0.5 & $43.4^{b}$ & \pm & 0.1 & $41.9^{a}$ & \pm & 0.3 \\
\hline Fat & & $27.2^{\mathrm{a}}$ & \pm & 0.3 & $27.1^{\mathrm{a}}$ & \pm & 0.3 & $25.2^{b}$ & \pm & 0.3 & $24.2^{c}$ & \pm & 0.3 \\
\hline Salt & & $1.51^{\mathrm{a}}$ & \pm & 0.01 & $1.53^{\mathrm{a}}$ & \pm & 0.01 & $1.71^{\mathrm{b}}$ & \pm & 0.05 & $1.53^{a}$ & \pm & 0.04 \\
\hline Total solids & TS & $57.9^{a}$ & \pm & 0.2 & $57.6^{a}$ & \pm & 0.5 & $56.6^{b}$ & \pm & 0.7 & $58.1^{\mathrm{a}}$ & \pm & 0.3 \\
\hline Fat in dry matter & FDM & $47.0^{\mathrm{a}}$ & \pm & 0.4 & $47.0^{\mathrm{a}}$ & \pm & 0.2 & $44.5^{b}$ & \pm & 0.5 & $41.7^{a}$ & \pm & 0.6 \\
\hline Salt in dry matter & SDM & $2.62^{\mathrm{a}}$ & \pm & 0.01 & $2.65^{a}$ & \pm & 0.04 & $2.99^{b}$ & \pm & 0.12 & $2.63^{a}$ & \pm & 0.07 \\
\hline Salt in moisture & $\mathrm{S} / \mathrm{M}$ & $3.59^{a}$ & \pm & 0.01 & $3.60^{\mathrm{a}}$ & \pm & 0.01 & $3.91^{b}$ & \pm & 0.14 & $3.64^{\mathrm{a}}$ & \pm & 0.06 \\
\hline
\end{tabular}

The results are expressed as the arithmetic mean and standard deviation $( \pm \sigma)$ from 6 measurements $(n=6)$

A-D - mean values in rows marked with different letters differ significantly at $p<0.05$

Data were analysed using factorial ANOVA 
TABLE 2. Content of volatile compounds in Dutch-type cheeses and cheese-like products during ripening [mg kg-1]

\begin{tabular}{|c|c|c|c|c|c|c|c|c|c|c|c|c|}
\hline \multirow{3}{*}{$\begin{array}{l}\text { Ripeninig } \\
\text { time [week] }\end{array}$} & \multicolumn{6}{|c|}{ Cheeses } & \multicolumn{6}{|c|}{ Cheese-like products } \\
\hline & \multicolumn{3}{|c|}{ control } & \multicolumn{3}{|c|}{ experimental } & \multicolumn{3}{|c|}{ control } & \multicolumn{3}{|c|}{ experimental } \\
\hline & \multicolumn{12}{|c|}{ acetic acid } \\
\hline 4 & $1983.84^{a}$ & \pm & 189.46 & $4742.21^{b}$ & \pm & 43.17 & $6038.75^{c}$ & \pm & 30.81 & $6082.18^{c}$ & \pm & 0.50 \\
\hline 6 & $1217.78^{b}$ & \pm & 34.97 & $4395.65^{a}$ & \pm & 13.90 & $4587.59^{a}$ & \pm & 387.55 & $6376.06^{c}$ & \pm & 268.00 \\
\hline \multirow[t]{2}{*}{10} & $1386.21^{b}$ & \pm & 1.56 & $4506.15^{a}$ & \pm & 164.53 & $5109.95^{a}$ & \pm & 222.43 & $5969.44^{c}$ & \pm & 175.79 \\
\hline & \multicolumn{12}{|c|}{ propionic acid } \\
\hline 4 & $18.74^{\mathrm{a}}$ & \pm & 1.91 & $16.77^{\mathrm{a}}$ & \pm & 0.30 & $15.43^{\mathrm{a}}$ & \pm & 1.32 & $31.17^{\mathrm{b}}$ & \pm & 0.69 \\
\hline 6 & $26.93^{a}$ & \pm & 0.38 & $28.23^{a}$ & \pm & 10.07 & $24.39^{a}$ & \pm & 0.76 & $23.76^{a}$ & \pm & 0.96 \\
\hline \multirow[t]{2}{*}{10} & $79.64^{\mathrm{a}}$ & \pm & 1.63 & $81.28^{\mathrm{a}}$ & \pm & 2.74 & $28.10^{\mathrm{b}}$ & \pm & 0.31 & $16.02^{c}$ & \pm & 0.64 \\
\hline & \multicolumn{12}{|c|}{ isobutyric acid } \\
\hline 4 & $7.56^{\mathrm{a}}$ & \pm & 0.14 & $7.60^{\mathrm{a}}$ & \pm & 0.27 & $8.81^{\mathrm{b}}$ & \pm & 0.02 & $12.1^{c}$ & \pm & 0.40 \\
\hline 6 & $7.13^{a}$ & \pm & 0.11 & $7.19^{a}$ & \pm & 1.21 & $11.82^{b}$ & \pm & 0.05 & $13.55^{b}$ & \pm & 0.31 \\
\hline \multirow[t]{2}{*}{10} & $7.38^{a}$ & \pm & 0.07 & $7.44^{\mathrm{a}}$ & \pm & 0.92 & $12.57^{b}$ & \pm & 0.08 & $20.04^{c}$ & \pm & 0.04 \\
\hline & \multicolumn{12}{|c|}{ butyric acid } \\
\hline 4 & $84.57^{c}$ & \pm & 5.53 & $156.17^{d}$ & \pm & 3.91 & $13.03^{\mathrm{a}}$ & \pm & 0.18 & $32.66^{b}$ & \pm & 1.08 \\
\hline 6 & $96.89^{b}$ & \pm & 3.43 & $149.89^{c}$ & \pm & 6.57 & $23.70^{\mathrm{a}}$ & \pm & 0.03 & $22.88^{\mathrm{a}}$ & \pm & 0.66 \\
\hline \multirow[t]{2}{*}{10} & $145.60^{\mathrm{a}}$ & \pm & 3.97 & $283.89^{c}$ & \pm & 6.43 & $26.34^{\mathrm{b}}$ & \pm & 0.76 & $136.91^{\mathrm{a}}$ & \pm & 2.39 \\
\hline & \multicolumn{12}{|c|}{ isovaleric acid } \\
\hline 4 & $4,05^{a}$ & \pm & 0.14 & $9.14^{b}$ & \pm & 1.76 & $6.55^{\mathrm{ab}}$ & \pm & 0.22 & $73.22^{c}$ & \pm & 0.69 \\
\hline 6 & $4.78^{b}$ & \pm & 0.10 & $12.72^{\mathrm{a}}$ & \pm & 0.34 & $14.52^{\mathrm{a}}$ & \pm & 0.49 & $115.69^{c}$ & \pm & 4.78 \\
\hline \multirow[t]{2}{*}{10} & $5.82^{b}$ & \pm & 0.15 & $23.72^{\mathrm{a}}$ & \pm & 1.64 & $21.70^{\mathrm{a}}$ & \pm & 0.42 & $150.61^{c}$ & \pm & 2.75 \\
\hline & \multicolumn{12}{|c|}{ valeric acid } \\
\hline 4 & $2.47^{b}$ & \pm & 0.07 & $4.04^{c}$ & \pm & 0.18 & $1.32^{\mathrm{a}}$ & \pm & 0.01 & $1.71^{\mathrm{a}}$ & \pm & 0.04 \\
\hline 6 & $2.62^{b}$ & \pm & 0.05 & $4.02^{c}$ & \pm & 0.69 & $1.61^{\mathrm{ab}}$ & \pm & 0.03 & $1.34^{\mathrm{a}}$ & \pm & 0.14 \\
\hline \multirow[t]{2}{*}{10} & $3.64^{b}$ & \pm & 0.12 & $5.35^{c}$ & \pm & 0.04 & $2.99^{a}$ & \pm & 0.09 & $2.67^{a}$ & \pm & 0.07 \\
\hline & \multicolumn{12}{|c|}{ isocaproic acid } \\
\hline 4 & $11.09^{a b}$ & \pm & 0.15 & $11.02^{b}$ & \pm & 0.02 & $11.38^{\mathrm{a}}$ & \pm & 0.03 & $11.36^{\mathrm{a}}$ & \pm & 0.14 \\
\hline 6 & $11.03^{a}$ & \pm & 0.08 & $11.06^{a}$ & \pm & 0.08 & $11.15^{\mathrm{a}}$ & \pm & 0.13 & $11.29^{b}$ & \pm & 0.08 \\
\hline \multirow[t]{2}{*}{10} & $11.04^{\mathrm{a}}$ & \pm & 0.01 & $11.16^{a}$ & \pm & 0.36 & $11.93^{\mathrm{a}}$ & \pm & 0.08 & $11.37^{\mathrm{a}}$ & \pm & 0.34 \\
\hline & \multicolumn{12}{|c|}{ caproic acid } \\
\hline 4 & $19.67^{b}$ & \pm & 2.32 & $26.80^{c}$ & \pm & 1.59 & $7.35^{\mathrm{a}}$ & \pm & 0.14 & $6.07^{a}$ & \pm & 0.08 \\
\hline 6 & $28.52^{\mathrm{b}}$ & \pm & 2.98 & $39.88^{c}$ & \pm & 2.92 & $9.07^{a}$ & \pm & 0.08 & $6.41^{\mathrm{a}}$ & \pm & 0.19 \\
\hline 10 & $43.14^{b}$ & \pm & 0.97 & $69.18^{c}$ & \pm & 2.33 & $9.12^{\mathrm{a}}$ & \pm & 0.17 & $8.11^{\mathrm{a}}$ & \pm & 0.85 \\
\hline
\end{tabular}

The results are expressed as the arithmetic mean and standard deviation $( \pm \sigma)$ from 4 measurements $(n=4)$ $A-D$ - mean values in rows marked with different letters differ significantly at $p<0.05$ Data were analysed using factorial ANOVA

by microorganisms colonizing milk, and it also is synthesized during the lipolytic activity of native enzymes in milk (Murphy et al., 2016). When present in small quantities, butyric acid imparts a characteristic cheesy aroma, which is particularly desirable in Italian and blue cheeses. In semi-hard cheeses high levels of butyric acid are undesirable (Curioni and Bosset, 2002; Collins et al., 2003), 
and they testify to butyric fermentation by Clostridium tyrobutyricum, a spore-forming anaerobic bacillus. High concentrations of butyric acid were reported in smoked cheese made from salted sheep's milk in the Tatra Mountains region of Poland, after steaming, salting and 3 days after production (Majcher et al., 2010). In the Portugese Serra da Estrela cheese made from sheep's milk, the content of butyric acid was estimated at $800 \mathrm{mg} / \mathrm{kg}$, and it exceeded $3000 \mathrm{mg} / \mathrm{kg}$ after only 35 days of ripening (Macedo and Malcata, 1997).

In our study, butyric acid levels increased in cheese-like products where NSLAB counts were reduced by the addition of $L$. paracasei due to substrate use (Table 2). In those products, butyric acid was formed in the presence of Clostridium tyrobutyricum (unpublished data). High levels of butyric acid in cheeses produced with the addition of L. casei have also been reported by other authors (Peralta et al. 2014; Zaręba et al. 2008; Cichosz et al. 2006b). According to some authors, however, Lactobacillus is capable of inhibiting the growth of butyrate-producing bacteria (Tưma et al. 2008; Matijašić et al., 2007). It should be noted that the cited research results are not contradictory because they concern different types of cheeses with various chemical composition, water activity and microbiological quality.

In this experiment, the addition of $L$. paracasei LPC-37 as the adjunct culture contributed to an increase in the content of butyric, isovaleric, valeric and caproic acid in experimental cheeses (Table 2). An increase in the extent of lipolysis in cheeses containing additional cultures, including Lactobacillus, has been demonstrated in numerous studies (Kumar et al., 2015; Hynes et al., 2002; Madkor et al., 1999). It should be noted, however, that bacterial cultures and strains have different lipolytic activity (Madkor et al., 1999).

Cheese-like products from experimental and control groups differed in their content of isovaleric acid (Table 2). Isovaleric acid is produced by the transamination of leucine to ketoisocaproic acid, which is then converted to isovaleric acid. The above reactions are mediated by active proteolytic enzymes of streptococci, in particular Lactobacillus (Ganesan et al., 2006; Thierry et al., 2004).

In the analysed cheeses, L. paracasei LPC-37 did not influence the production of isobutyric or isocaproic acid (Table 2). Volatile FFAs are synthesized from branched amino acids, and they are responsible for undesirable aromas such as sweaty, rancid, fecal and rotten fruit, especially at high concentrations (Rychlik and Bosste, 2001; Thierry et al., 2002). Branched chain fatty acids were not detected in Belgian Gouda-type cheeses produced from raw milk after 6 weeks of ripening, but they were present in cheeses made from pasteurized milk (Van Leuven et al., 2008).

The content of nearly all volatile FFAs increased during ripening of cheeses and cheese-like products (Table 2). Many authors have reported an increase in the extent of lipolysis during ripening of various types of cheeses (Atasoy and Türkoğlu, 2008; Malacarne et al., 2009; Voigt et al., 2010).

The analysed Dutch-type cheeses and cheeselike products had a different sensory profile (Table 5). The replacement of milk fat with palm oil increased the content of acetic acid, probably due to higher counts of citrate-fermenting bacteria. Cheese-like products were characterized by a lower content of butyric, valeric and caproic acid due to the replacement of milk fat with palm oil which has a different fatty acid profile (Table 2). The content of volatile FFAs was also very low in Swiss cheese-like products manufactured with the addition of high oleic sunflower oil in comparison with cheeses containing milk fat (Yu and Hammond, 2000).

After 4 weeks of ripening, Dutch-type cheeses were characterized by higher colour brightness $\left(L^{*}\right)$ than cheese-like products (Table 3 ). During ripening, colour brightness decreased in cheeses $\left(R^{2}=-\right.$ $0.87, p<0.05)$ and in cheese-like products $\left(R^{2}=-0.76\right.$, $p<0.05)$. The decrease in colour brightness led to a drop in the $\mathrm{WI}$ of Dutch-type cheeses $\left(R^{2}=-0.61\right.$, $p<0.05)$ and cheese-like products $\left(R^{2}=-0.6, p<0.05\right)$ during ripening (Table 4). The values of WI differed significantly in control and experimental products and were always higher in experimental products (Table 3). In a study by Pavia et al. (1999), parameter $L^{*}$ was negatively correlated with the protein content of hard cheeses. A non-homogeneous protein matrix was produced in cheeses with a lower water content and a higher content of soluble nitrogen compounds, which affected colour reflection and, consequently, decreased the value of parameter $L^{*}$ (Table 3). 
TABELE 3. Colour attributes for cheeses and cheese-like products

\begin{tabular}{|c|c|c|c|c|c|c|c|c|c|c|c|c|}
\hline \multirow{3}{*}{$\begin{array}{l}\text { Ripeninig time } \\
\text { [week] }\end{array}$} & \multicolumn{6}{|c|}{ Cheeses } & \multicolumn{6}{|c|}{ Cheese-like products } \\
\hline & \multicolumn{3}{|c|}{ control } & \multicolumn{3}{|c|}{ experimental } & \multicolumn{3}{|c|}{ control } & \multicolumn{3}{|c|}{ experimental } \\
\hline & \multicolumn{12}{|c|}{$L^{*}$} \\
\hline 4 & $73.7^{\mathrm{b}}$ & \pm & 0.1 & $73.4^{\mathrm{b}}$ & \pm & 0.4 & $70.5^{a}$ & \pm & 1.0 & $71.7^{\mathrm{a}}$ & \pm & 0.9 \\
\hline 6 & $73.4^{c}$ & \pm & 0.2 & $72.5^{b c}$ & \pm & 0.2 & $69.4^{\mathrm{a}}$ & \pm & 1.5 & $70.7^{\mathrm{ab}}$ & \pm & 0.9 \\
\hline \multirow[t]{2}{*}{10} & $71.6^{\mathrm{b}}$ & \pm & 0.3 & $71.7^{b}$ & \pm & 0.6 & $67.3^{\mathrm{a}}$ & \pm & 0.9 & $68.7^{\mathrm{a}}$ & \pm & 0.9 \\
\hline & \multicolumn{12}{|c|}{$a^{*}$} \\
\hline 4 & $4.76^{\mathrm{a}}$ & \pm & 0.23 & $4.52^{\mathrm{a}}$ & \pm & 0.22 & $5.63^{b}$ & \pm & 0.3 & $4.73^{a}$ & \pm & 0.7 \\
\hline 6 & $4.86^{a}$ & \pm & 0.13 & $4.20^{b}$ & \pm & 0.40 & $4.80^{\mathrm{a}}$ & \pm & 0.30 & $4.30^{\mathrm{ab}}$ & \pm & 0.30 \\
\hline \multirow[t]{2}{*}{10} & $4.74^{b}$ & \pm & 0.15 & $4.21^{\mathrm{a}}$ & \pm & 0.09 & $5.10^{c}$ & \pm & 0.18 & $4.31^{\mathrm{a}}$ & \pm & 0.20 \\
\hline & \multicolumn{12}{|c|}{$b^{*}$} \\
\hline 4 & $24.7^{c}$ & \pm & 0.2 & $22.1^{\mathrm{a}}$ & \pm & 0.1 & $25.7^{d}$ & \pm & 0.5 & $22.69^{b}$ & \pm & 0.04 \\
\hline 6 & $25.2^{c}$ & \pm & 0.3 & $22.3^{a}$ & \pm & 0.1 & $26.6^{d}$ & \pm & 0.1 & $23.29^{b}$ & \pm & 0.27 \\
\hline \multirow[t]{2}{*}{10} & $25.5^{c}$ & \pm & 0.2 & $22.6^{\mathrm{a}}$ & \pm & 0.2 & $26.93^{d}$ & \pm & 0.07 & $24.06^{b}$ & \pm & 0.25 \\
\hline & \multicolumn{12}{|c|}{$\mathrm{H}^{*}$} \\
\hline 4 & $79.1^{\mathrm{a}}$ & \pm & 0.5 & $78.4^{\mathrm{a}}$ & \pm & 0.6 & $77.6^{\mathrm{a}}$ & \pm & 0.6 & $78.3^{a}$ & \pm & 1.6 \\
\hline 6 & $79.1^{\mathrm{a}}$ & \pm & 0.3 & $79.3^{a}$ & \pm & 1.0 & $79.7^{\mathrm{a}}$ & \pm & 0.7 & $79.6^{a}$ & \pm & 0.8 \\
\hline \multirow[t]{2}{*}{10} & $79.5^{a}$ & \pm & 0.3 & $79.4^{a}$ & \pm & 0.2 & $79.3^{a}$ & \pm & 0.4 & $79.9^{a}$ & \pm & 0.5 \\
\hline & \multicolumn{12}{|c|}{$C^{*}$} \\
\hline 4 & $25.2^{c}$ & \pm & 0.1 & $22.5^{a}$ & \pm & 0.1 & $26.3^{d}$ & \pm & 0.5 & $23.2^{b}$ & \pm & 0.2 \\
\hline 6 & $25.7^{c}$ & \pm & 0.2 & $22.7^{\mathrm{a}}$ & \pm & 0.1 & $27.0^{d}$ & \pm & 0.1 & $23.7^{b}$ & \pm & 0.3 \\
\hline \multirow[t]{2}{*}{10} & $25.9^{c}$ & \pm & 0.2 & $22.9^{\mathrm{a}}$ & \pm & 0.2 & $27.4^{d}$ & \pm & 0.1 & $24.5^{b}$ & \pm & 0.3 \\
\hline & \multicolumn{12}{|c|}{ WI } \\
\hline 4 & $63.6^{a}$ & \pm & 0.1 & $65.1^{c}$ & \pm & 0.3 & $60.5^{b}$ & \pm & 1.1 & $63.4^{\mathrm{a}}$ & \pm & 0.7 \\
\hline 6 & $63.1^{\mathrm{ab}}$ & \pm & 0.3 & $64.4^{b}$ & \pm & 0.1 & $59.1^{c}$ & \pm & 1.2 & $62.3^{a}$ & \pm & 0.8 \\
\hline \multirow[t]{2}{*}{10} & $61.6^{a}$ & \pm & 0.3 & $63.6^{c}$ & \pm & 0.6 & $57.3^{b}$ & \pm & 0.8 & $60.3^{a}$ & \pm & 0.9 \\
\hline & \multicolumn{12}{|c|}{$\mathrm{YI}$} \\
\hline 4 & $48.0^{c}$ & \pm & 0.3 & $43.0^{\mathrm{a}}$ & \pm & 0.4 & $52.1^{d}$ & \pm & 1.7 & $45.2^{b}$ & \pm & 0.6 \\
\hline 6 & $49.0^{c}$ & \pm & 0.6 & $43.9^{\mathrm{a}}$ & \pm & 0.1 & $54.8^{d}$ & \pm & 1.4 & $47.1^{b}$ & \pm & 1.0 \\
\hline 10 & $50.8^{\mathrm{a}}$ & \pm & 0.6 & $44.9^{b}$ & \pm & 0.8 & $57.2^{\mathrm{c}}$ & \pm & 0.9 & $50.1^{\mathrm{a}}$ & \pm & 1.2 \\
\hline
\end{tabular}

The results are expressed as the arithmetic mean value and standard deviation $(\bar{x} \pm \sigma)$ from 4 measurements $(n=4)$ A-D - mean values in rows marked with different letters differ significantly at $p<0.05$

Data were analysed using factorial ANOVA

$L^{*}, a^{*}$ and $b^{*}$ values for light to dark, red to green, and yellow to blue respectively

Chroma $\left(\mathrm{C}^{*}\right)$, hue $\left(\mathrm{H}^{*}\right)$, Whiteness index $(\mathrm{WI})$ and Yellowness index $(\mathrm{YI})$ were calculated from data collected from reference

The contribution of yellowness $\left(b^{*}\right)$ increased gradually during ripening of the analysed cheeses and cheese-like products. Control products were characterized by significantly higher values of $b^{*}$ than experimental products. The $\mathrm{YI}$ of cheeses and cheese-like products also increased during ripen- ing (Table 3). A decrease in colour brightness and an increase in the contribution of yellowness have also been reported by other authors (Dufossé et al., 2005; Marchesini et al., 2009). Those observations can probably be attributed to changes in the chemical composition of cheese during ripening 
TABLE 4. Correlations between colour attributes and ripening time

\begin{tabular}{|c|c|c|c|c|c|c|c|}
\hline & $L^{*}$ & $a^{*}$ & $b^{*}$ & $\mathrm{H}^{*}$ & $C^{*}$ & WI & YI \\
\hline \multicolumn{8}{|l|}{ Cheeses } \\
\hline ripening time & $-0.87^{*}$ & -0.18 & $0.45^{*}$ & $0.47^{*}$ & $0.43^{*}$ & $-0.61^{*}$ & $0.47^{*}$ \\
\hline \multicolumn{8}{|c|}{ Cheese-like products } \\
\hline ripening time & $-0.76^{*}$ & -0.32 & $0.47^{*}$ & $0.56^{*}$ & $0.46^{*}$ & $-0.6^{*}$ & $0.49^{*}$ \\
\hline
\end{tabular}

Spearman's rank correlation coefficient ${ }^{*} \mathrm{p}<0.05$

$L^{*}$ - colour lightness; $a^{*}$ and $b^{*}$ - chromaticity of the light source; $C^{*}$ - chroma; $\mathrm{H}^{*}$ - hue; WI - Whiteness index; YI - Yellowness index

(increase in dry matter content) and lipolysis (Avila et al., 2008). In the work of Dufossé et al. (2005), the contribution of yellowness $\left(b^{*}\right)$ and redness $\left(a^{*}\right)$ was highly correlated with fat content $\left(R^{2}=0.77\right.$ and $R^{2}=0.72$, respectively; $P<0.01$ ). According to Ginzinger et al. (1999), YI values are significantly correlated with the season of milk collection and the ripening time of Austrian Bergkäse cheese.

Contrary to the results reported by Avila et al. (2008), the addition of Lactobacillus paracasei LPC-37 as an adjunct culture did not influence colour brightness $\left(L^{*}\right)$ of the evaluated cheeses and cheese-like products. However, the applied adjunct culture contributed to a significant decrease in the contribution of redness $\left(a^{*}\right)$ and yellowness $\left(b^{*}\right)$ in the experimental cheeses and cheese-like products. The analysed adjunct culture also led to a decrease in colour saturation $\left(C^{*}\right)$, an increase in WI values and a decrease in $\mathrm{YI}$ values. The colour(parameters $L^{*}$ and $b^{*}$ ) of Brazilian semi-hard Coalho cheese, produced from goat's milk with the addition of a probiotic strain of Lactobacillus paracasei (L. casei-01, 2910976), did not differ significantly from the colour of cheeses containing Lactococcus lactis ssp. lactis and Lactococcus lactis ssp. cremoris strains after salting or after 7 and 14 days of ripening at a temperature of $10^{\circ} \mathrm{C}$. However, after 21 days of ripening, cheeses with the addition of the $L$. paracasei culture were characterized by significantly higher values of $L^{*}$ and lower values of $b^{*}$ than the cheeses containing mesophilic streptococci only (Oliveira et al., 2012).

In our study, the replacement of milk fat with palm oil led to a significant decrease in colour brightness $L^{*}$ and an increase in the values of $b^{*}, C^{*}$ and YI (Table 3). By contrast, Dinkçi et al. (2011) replaced milk fat with a blend of vegetable oils in Turkish Kashar-like cheese and observed a significant increase in parameter $L^{*}$ and a decrease in the values of $b^{*}$ and $C^{*}$. Cheeses made from the milk of cows whose diets were supplemented with fish oil $\left(500 \mathrm{~g} \mathrm{~d}^{-1} \mathrm{cow}^{-1}\right)$ and fish oil with hydrogenated palm oil $\left(250 \mathrm{~g} \mathrm{~d}^{-1} \mathrm{cow}^{-1}+250 \mathrm{~g} \mathrm{~d}^{-1} \mathrm{cow}^{-1}\right)$ were characterized by higher values of $L^{*}$ and $b^{*}$ than control cheeses made from the milk of non-supplemented cows (Vargas-Bello-Pérez et al., 2015). In this study, the overall sensory evaluation with weighting factors did not reveal significant differences between control and experimental cheeses. The addition of L. paracasei LPC-37 as the adjunct culture did not influence their sensory quality. Cheese-like products scored significantly lower than Dutch-type cheeses in the sensory evaluation. The replacement of milk fat with palm oil significantly deteriorated the sensory quality of cheese-like products. The eyes of cheese-like products should be not numerous, round and evenly distributed across the cross section, similarly to those of Dutch-type cheeses. However, cheese-like products scored much lower for eye formation than cheeses. The colour scores of cheese-like products during ripening and storage were relatively high, but control products were slightly discoloured.

Cheese-like products were characterized by a tough and gummy consistency and low elasticity. A sample squeezed between the thumb and the forefinger remained permanently deformed, which is typical of products where milk fat was replaced with vegetable oil, and points to the lack of springiness. Immediately after salting, cheese-like products had unpleasant and bland odour and taste, which were not typical of cheese. Experimental cheese-like products, produced with the use of the probiotic strain L. paracasei LPC-37, scored each time higher for odour and taste than control products. Despite the above, the experimental cheeselike products containing L. paracasei LPC-37 scored higher than control products (Table 5). 
TABLE 5. Overall sensory evaluation with weighting factors

\begin{tabular}{|c|c|c|c|c|c|c|c|c|c|c|c|c|}
\hline \multirow{3}{*}{$\begin{array}{l}\begin{array}{c}\text { Ripening time } \\
\text { [week] }\end{array} \\
4\end{array}$} & \multicolumn{6}{|c|}{ Cheeses } & \multicolumn{6}{|c|}{ Cheese-like products } \\
\hline & \multicolumn{3}{|c|}{ control } & \multicolumn{3}{|c|}{ experimental } & \multicolumn{3}{|c|}{ control } & \multicolumn{3}{|c|}{ experimental } \\
\hline & $4.9^{c}$ & \pm & 0.2 & $4.8^{c}$ & \pm & 0.2 & $2.9^{a}$ & \pm & 0.1 & $3.3^{b}$ & \pm & 0.2 \\
\hline 6 & $4.8^{c}$ & \pm & 0.2 & $5.0^{c}$ & \pm & 0.2 & $3.3^{a}$ & \pm & 0.1 & $3.6^{b}$ & \pm & 0.1 \\
\hline 10 & $4.7^{c}$ & \pm & 0.1 & $4.8^{c}$ & \pm & 0.2 & $3.4^{a}$ & \pm & 0.1 & $3.9^{b}$ & \pm & 0.1 \\
\hline
\end{tabular}

The results were expressed as arithmetic mean value and standard deviation $(\bar{x} \pm \sigma)$ from 6 measurements $(n=6)$ A-D - mean values in rows marked with different letters differ significantly at $p<0.05$

Data were analysed using factorial ANOVA.

Mean values marked with the same letters do not differ significantly between control and experimental products at $p<0.05$

According to many authors, the quality of ripened cheese is determined by the predominant NSLAB strains (Crow et al., 2001; Swearingen et al., 2001; Kieronczyk et al., 2003). High NSLAB counts can intensify the product's odour and taste, and they can shorten ripening time (Cichosz et al. 2006a; Crow et al. 2001). For this reason, selected Lactobacillus strains are used to modify the odour and taste of the final product (Buriti et al., 2005; Buriti et al., 2007). Previous studies demonstrated that $L$. paracasei strains exerted varied effects on the sensory quality of ripened cheeses. L. paracasei had both positive and negative effects on Danish Danbo cheese, subject to the applied strain (Antonsson et al., 2003). Lynch et al. (1996) found that Cheddar cheese made with the addition of L. paracasei subsp. paracasei was characterized by a more intense odour and greater bitterness than control cheeses. Ong et al. (2007) also found that the addition of $L$. paracasei contributed to a bitter taste of probiotic cheeses. In a study evaluating 2 Lactobacillus paracasei strains (R-40926 and R-40937) isolated from Gouda cheeses (made from raw milk), the analysed strains had varied effects on the sensory quality of cheese. Cheeses made with strain R-40926 contained mostly products of proteolytic degradation, whereas cheeses supplemented with L. paracasei R-40926 contained mostly volatile compounds (volatile FFAs, $y$ - and $\delta$-lactones) from the lipolytic breakdown of fat, as well as amino acids and their derivatives (branched aldehydes, sulfur compounds). The above data suggest that strain L. paracasei R-40926 displays both proteolytic and lipolytic activities, whereas strain $L$. paracasei R-40937 has mainly proteolytic activity (Van Hoorde et al., 2010). In some studies, probiotic $L A B$ did not influence the sensory attributes of cheeses (Gardiner et al., 1998, Santillo and Albenzio, 2008).

El-Salam (2015) demonstrated that the replacement of milk fat had a negative impact on the sensory quality of cheese. The cited author evaluated the effects of milk fat replacement with sunflower oil and the addition of whey protein concentrate to fresh Tallaga cheese. In a sensory evaluation, control cheeses ranked significantly higher than experimental cheeses (64). Original Turkish Kashar cheese also scored much higher in a sensory analysis than Kashar-like cheese containing a vegetable oil blend. The quality of control cheeses and cheese-like products deteriorated with ripening time (Dinkçi et al., 2011).

\section{Conclusion}

In the present study, the addition of $L$. paracasei LPC-37 as the adjunct culture to Dutch-type cheeses and cheese-like products increased the content of volatile FFAs, decreased the contribution of redness $a^{*}$ and yellowness $b^{*}$, decreased colour saturation $C^{*}$, increased the values of $\mathrm{WI}$ and decreased the values of $\mathrm{YI}$ in cheese and cheese-like products. The use of L. paracasei LPC-37 as the adjunct culture had no effect on the sensory quality of Dutchtype cheeses.

The replacement of milk fat with palm oil contributed to differences in the sensory profile and colour of cheese-like products and deteriorated their sensory quality. However, the addition of $L$. paracasei LPC-37 improved the sensory characteristics of cheese-like products but they are still inferior compared to cheeses. 
The authors are grateful to dairy cooperative in Giżycko (Poland) and LabMlek Dairy Laboratory for assistance in performing the experiment.

\section{Učinak zamjene mliječne masti i dodatka soja Lactobacillus paracasei LPC-37 na senzorska svojstva sira}

\section{Sažetak}

Tržište sireva sa zrenjem brzo raste i izrazito je kompetitivno. Proizvođači mliječnih proizvoda proširili su svoj asortiman na proizvode slične siru koji sadrže zamjene za mliječnu mast. Takvi proizvodi postaju sve popularniji kako među proizvođačima hrane, tako među potrošačima koji su u potrazi za jeftinijim zamjenama za sir. Mast određuje senzorska svojstva sira. Međutim, senzorska kvaliteta sira može se modificirati i primjenom pomoćnih starter kultura. U ovom istraživanju ispitivan je utjecaj uporabe palminog ulja kao zamjene za mliječnu mast i soja Lactobacillus paracasei LPC-37 kao pomoćne starter kulture na senzorska svojstva nizozemskog tipa sira te zamjena za sir tijekom razdoblja zrenja. Svim uzorcima određivan je kemijski sastav, sadržaj hlapivih sastojaka i boja. Zamjena mliječne masti palminim uljem uzrokovala je razlike u senzorskom profilu i boji zamjena za sir te je smanjila senzorsku kvalitetu ovih proizvoda. Međutim, dodatak soja L. paracasei LPC-37 poboljšao je senzorska svojstva zamjena za sir.

\section{Ključne riječi: Lactobacillus paracasei LPC-37, sir, palmino ulje, okus, boja}

\section{References}

1. Akın, N., Aydemir, S., Koçak, C., Yıldız, M.A. (2003): Changes of free fatty acid contents and sensory properties of white pickled cheese during ripening. Food Chemistry 80, 77-83. https://doi.org/10.1016/S0308-8146(02)00242-X

2. Aljewicz, M., Cichosz, G., Nalepa, B., Kowalska, M. (2014): Influence of the probiotic Lactobacillus acidophilus NCFM and Lactobacillus rhamnosus HNOO1 on proteolysis patterns of edam Cheese. Food Technology and Biotechnology 52 (4), 439-447. https://doi.org/10.17113/ftb.52.04.14.3659

3. Antonsson, M., Ardo, Y., Nilsson, B.F., Molin G. (2002): Screening and selection of Lactobacillus strains for use as adjunct cultures in production of semi-hard cheese. Journal of Dairy Research 69, 457-472. https://doi.org/10.1017/S0022029902005563

4. Antonsson, M., Molin, G., Ardö, Y. (2003): Lactobacillus strains isolated from Danbo cheese as adjunct cultures in a cheese model system. International Journal of Food Microbiology 85(1), 159-169. https://doi.org/10.1016/s0168-1605(02)00536-6

5. Atasoy, A.F., Türkoğlu, H. (2008): Changes of composition and free fatty acid contents of Urfa cheeses (a whitebrined Turkish cheese) during ripening Effects of heat treatments and starter cultures. Food Chemistry 110, 598-604. https://doi.org/10.1016/j.foodchem.2008.02.046
6. Avila, M., Garde, S., Nunez, M. (2008): The influence of some manufacturing and ripening parameters on the colour of ewes milk cheese. Milchwissenschaft 2, 160-164.

7. Broadbent, JR., Houck, K., Johnson, ME., Oberg CJ. (2003): Influence of adjunct use and cheese microenvironment on nonstarter bacteria in reduced-fat cheddar-type cheese. Journal of Dairy Science 86, 2773-2782. https://doi.org/10.3168/jds.S0022-0302(03)73874-0

8. Buriti, F.C.A., Cardarelli, H.R., Saad, S.M.I. (2007): Biopreservation by Lactobacillus paracasei in co-culture with Streptococcus thermophilus in potentially probiotic and synbiotic fresh cream-cheeses. Journal of Food Protection 70, 228-235. https://doi.org/10.4315/0362-028X-70.1.228

9. Buriti, F.C.A., da Rocha, J.S., Assis, E.G., Saad, S.M.I. (2005): Probiotic potential of Minas fresh cheese prepared with the addition of Lactobacillus paracasei. LWT-Food Science and Technology 38(2), 173-180. https://doi.org/10.1016/j.lwt.2004.05.012

10. Cakir, E., Clark, S. (2009): Swiss Cheese and Related Products. In Clark S, Bodyfelt F W, editors. The sensory evaluation of dairy products. Springer, New York. pp 427 458.

11. Cichosz, G., Zalecka, A., Kornacki, M. (2003): Effect of paracasein degradation on sensory properties of Gouda cheese. Food/Nahrung 47 (6), 383-387. https://doi.org/10.1002/food.200390086 
12. Cichosz, G., Borejszo, Z., Tomera, K., Kornacki, M. (2006b): Aroma compounds in Gouda cheese produced with addition of probiotic strains. Polish Journal of Natural Science 21 (2), 987-997.

13. Cichosz, G., Zalecka, A., Lenkiewicz, M. (2006a): The influence of streptococci and lactobacilli on proteolysis in Gouda cheese. Milchwissenschaft 5/6, 297-300

14. Collins, Y.F., McSweeney, P.L.H., Wilkinson, M.G. (2003): Lipolysis and free fatty acid catabolism in cheese a review of current knowledge. International Dairy Journal 13 (11), 841-866. https://doi.org/10.1016/S0958-6946(03)00109-2

15. Courtin, P., Nardi, M., Wegmann, U., Joutsjoki, V., Ogier, J.C., Gripon, J.C., Pavia, A., Henrich, B., Monnet, V. (2002): Accelerating cheese proteolysis by enriching Lactococcus lactis proteolytic system with lactobacilli peptidases. International Dairy Journal 12 (5), 447-454. https://doi.org/10.1016/S0958-6946(02)00022-5

16. Crow, V., Curry, B., Hayes, M. (2001): The ecology of nonstarter lactic acid bacteria (NSLAB) and their use as adjuncts in New Zealand Cheddar. International Dairy Journal 11, 275-283.

https://doi.org/10.1016/S0958-6946(01)00057-7

17. Curioni, P.M.G., Bosset, J.O. (2002): Key odourants in various cheese types as determined by gas chromatographyolfactometry. International Dairy Journal 12, 959-984. https://doi.org/10.1016/S0958-6946(02)00124-3

18. Dinkçi, N., Kesenkaş, H., Seçkin, AK., Kınık, Ö., Gönç, S. (2011): Influence of a vegetable fat blend on the texture, microstructure and sensory properties of Kashar cheese. Grasas y aceites 62 (3), 275-283. https://doi.org/10.3989/gya.091810

19. Dufossé, L., Galaup, P., Carlet, P., Flamin, C., Valla, A. (2005): Spectrocolorimetry in the CIE L*a*b* colourspace as useful tool for monitoring the ripening process and the quality of PDO red-smear soft cheeses. Food Research International 38, 919-924. https://doi.org/10.1016/j.foodres.2005.02.013

20. Dustrerhoft, E-M., van den Berg, G. (2007): Dutch-type cheese. In: McSweeney PLH, editor, Cheese Problems Solved, Woodhouse Publishing Ltd. pp 230-245.

21. El-Salam, B.A.A. (2015): Effect of milk fat replacement with vegetable oil and/or whey protein concentrate on microstructure, texture and sensory characteristics of fresh soft cheese. International Dairy Journal 10 (3), 117-125. https://doi.org/10.3923/ijds.2015.117.125

22. Everett, D.W., Auty, M.A. (2008): Cheese structure and current methods of analysis. International Dairy Journal 18 (7), 759 773. https://doi.org/10.1016/j.idairyj.2008.03.012

23. Ganesan, B., Dobrowolski, P., Weimer, B.C. (2006) Identification of the leucine-to-2-methylbutyric catabolic pathway acid of Lactococcus lactis. Applied and Environmental Microbiology 72 (6), 4264-4273. https://doi.org/10.1128/AEM.00448-06

24. Gardiner, G., Ross, R.P., Collins, J.K., Fitzgerald, G., Stanton, C. (1998): Development of a probiotic cheddar cheese containing human-derived Lactobacillus paracasei strains. Applied and Environmental Microbiology 64 (6), 2192-2199.

25. Ginzinger, W., Jaros, D., Lavanchy, P., Rohm, H. (1999): Raw milk flora affects composition and quality of Bergkäse. 3. Physical and sensory properties, and conclusions. Le Lait 79, 411-421. https://doi.org/10.1051/lait:1999434
26. Gómez-Ruiz, J.Á., Cabezas, L., Martínez-Castro, I., GonzálezViñas, M.Á., Poveda, J.M. (2008): Influence of a defined-strain starter and Lactobacillus plantarum as adjunct culture on volatile compounds and sensory characteristics of Manchego cheese. European Food Research and Technology 227 (1), 181-190. https://doi.org/10.1016/j.foodchem.2005.09.011

27. Hynes, E., Ogier, J.C., Lamberet, G., Delacroix-Buchet, A. (2002): The influence of starter and adjunct lactobacilli culture on the ripening of washed curd cheeses. The Brazilian Journal of Chemical Engineering 19 (4), 397-402. http://dx.doi.org/10.1590/S0104-66322002000400007

28. ISO 22935-3-2009 Milk and milk products - Sensory analysis - Part 3 Guidance on a method for evaluation of compliance with product specifications for sensory properties by scoring.

29. ISO 4121 2003. Sensory analysis - Guidelines for the use of quantitative response scales. Geneva, Switzerland, International Organization for Standardization (ISO) 2003

30. ISO 8589 2007. Sensory analysis - General guidance for the design of test room. Geneva, Switzerland, International Organization for Standardization (ISO) 2007

31. ISO 8586 2012. Sensory analysis - General guidelines for the selection, training and monitoring of selected assessors and expert sensory assessors. Geneva, Switzerland, International Organization for Standardization (ISO) 2012

32. Kieronczyk, A., Skeie, S., Langsrud, T., Yvon, M. (2003): Cooperation between Lactococcus lactis and non-starter lactobacilli in the formation of cheese aroma from amino acids. Applied and Environmental Microbiology 69, 734-739. https://doi.org/10.1128/aem.69.2.734-739.2003

33. Kumar, S., Kanawjia, SK., Kumar, S. (2015): Incorporation of Lactobacillus adjuncts culture to improve the quality of Fetatype cheese made using buffalo milk. Journal of Food Science and Technology 52 (8), 5021-5029. https://doi.org/10.1007/s13197-014-1560-y

34. Limsowtin, G.K.Y., Broome, M.C., Powell, I.B. (2003) Lactic acid bacteria taxonomy. In: Roginski H., Fuquay JW., Fox PF., editors. Encyclopedia of dairy sciences, Academic Press. pp. 1470-1478.

35. Lobato-Calleros, C., Ramirez-Santiago, C., OsorioSantiago, V..., Vernon-Carter, E.J., Hornelas-Uribe, Y. (2002): Microstructure and texture of manchego cheese-like products made with canola oil, lipophilic and hydrophilic emulsifiers. Journal of Texture Studies 33, 165-182. https://doi.org/10.1111/j.1745-4603.2002.tb01343.x

36. Lobato-Calleros, C., Velazquez-Varela, J., Sanchez-Garcia, J., Vernon-Carter, E.J. (2003): Dynamic rheology of Mexican Manchego cheese-like products containing canola oil and emulsifier blends. Food Research International 36, 81-90. https://doi.org/10.1016/S0963-9969(02)00111-4

37. Lynch, C.M., McSweeney, P.L.H., Fox, P.F., Cogan, T.M., Drinan, FD. (1996): Manufacture of Cheddar cheese with and without adjunct lactobacilli under controlled microbiological conditions International Dairy Journal 6 (8), 851-867. https://doi.org/10.1016/0958-6946(96)00019-2

38. Macedo, A.C., Malcata, F.X. (1996): Changes in the major free fatty acids in Serra cheese during ripening. International Dairy Journal 6, 1087-1097. https://doi.org/10.1016/S0958-6946(96)00032-5 
39. Madkor, S.A., El Soda, M., Tong, P.S. (1999): Evaluation of commercial adjuncts for use in cheese ripening 2 Ripening aspects and flavour development in cheese and curd slurries prepared with adjunct lactobacilli. Milchwissenschaft 54, 133-137.

40. Majcher, M., Ławrowski, P., Jeleń, H. (2010): Comparison of original and adulterated Oscypek cheese based on volatile and sensory profiles. Acta Scientiarum Polonorum Technologia Alimentaria 9 (3), 265-275.

41. Malacarne, M., Summer, A., Franceschi, P., Formaggioni, P., Pecorari, M., Panari, G., Mariani, P. (2009): Free fatty acid profile of Parmigiano-Reggiano cheese throughout ripening: Comparison between the inner and outer regions of the wheel. International Dairy Journal 19, 637-641. https://doi.org/10.1016/j.idairyj.2009.04.004

42. Marchesini, G., Balzan, S., Segato, S., Novelli, E., Andrighetto, I. (2009): Colour traits in the evaluation of the ripening period of Asiago cheese. Italian Journal of Animal Science 8 (2), 412-413. https://doi.org/10.4081/ijas.2009.s2.412

43. Matijašić, B.B., Rajšp, M.K., Perko, B., Rogelj, I. (2007): Inhibition of Clostridium tyrobutyricum in cheese by Lactobacillus gasseri. International Dairy Journal 17 (2), 157 166. https://doi.org/10.1016/j.idairyj.2006.01.011

44. Murphy, S.C., Martin, N.H, Barbano, D.M, Wiedmann, M. (2016): Influence of raw milk quality on processed dairy products: How do raw milk quality test results relate to product quality and yield? Journal of Dairy Science 99(12), 10128-10149. https://doi.org/10.3168/jds.2016-11172

45. Oliveira, M.E.G., Fernandes Garcia, E., de Cássia Ramos do Egypto Queiroga, R., Leite de Souza, E. (2012): Technological, physicochemical and sensory characteristics of a Brazilian semi-hard goat cheese (coalho) with added probiotic lactic acid bacteria. Scientia Agricola 69 (6), 370379.

\subsection{0/S0103-90162012000600005}

46. Ong, L., Henriksson, A., Shah, N.P. (2007): Chemical analysis and sensory evaluation of Cheddar cheese produced with Lactobacillus acidophilus, Lb casei, Lb paracasei or Bifidobacterium spp. International Dairy Journal 17, 937-945. https://doi.org/10.1016/j.idairyj.2007.01.002

47. Pavia, M., Guamis, B., Trujillo, A.J., Capellas, M., Ferragut, V. (1998): Changes in microstructural, textural and colour characteristics during ripening of Manchego-type cheese salted by brine vacuum impregnation. International Dairy Journal 9 (2), 91-98. https://doi.org/10.1016/S0958-6946(99)00027-8

48. Peralta, G.H., Wolf, I.V., Bergamini, C.V., Perotti, M.C., Hynes, E.R. (2014): Evaluation of volatile compounds produced by Lactobacillus paracasei 190 in a hard-cooked cheese model using solid-phase microextraction. Dairy Science \& Technology 94 (1), 73-81. https://doi.org/10.1007/s13594-013-0143-4

49. Ramirez-Navas, J.S., de Stouvenel, A.R. (2012): Characterization of Colombian quesillo cheese by spectrocolorimetry. Vitae 19 (2), 178-185.

50. Rychlik, M., Bosset, J.O. (2001): Flavour and off-flavour compounds of Swiss Gruye `re cheese Evaluation of potent odourants. International Dairy Journal 11, 895-901. https://doi.org/10.1016/S0958-6946(01)00108-X
51. Santillo, A., Albenzio, M. (2008): Influence of lamb rennet paste containing probiotic on proteolysis and rheological properties of Pecorino cheese. Journal of Dairy Science 91 1733-1742 https://doi.org/10.3168/jds.2007-0735

52. Settanni, L., Moschetti, G. (2010): Non-starter lactic acid bacteria used to improve cheese quality and provide health benefits. Food Microbiology 27 (6), 691-697. https://doi.org/10.1016/j.fm.2010.05.023

53. Swearingen, P.A., O'Sullivan, D.J., Warthesen, J.J. (2001): Isolation, characterization, and influence of native, nonstarter lactic acid bacteria on cheddar cheese quality. Journal of Dairy Science 84, 50-59. https://doi.org/10.3168/jds.S0022-0302(01)74451-7

54. Thierry, A., Maillard, M-B. (2002): Production of cheese flavour compounds derived from amino acid catabolism by Propionibacterium freudenreichii. Le Lait 82, 17-32. https://doi.org/10.1051/lait:2001002

55. Thierry, A., Richoux, R., Kerjean, J.R. (2004): Isovaleric acid is mainly produced by Propionibacterium freudenreichii in Swiss cheese. International Dairy Journal 14, 801-807. https://doi. org/10.1016/j.idairyj.2004.02.002

56. Tůma, Š., Kučerová, K., Plocková, M. (2008): Isolation of anticlostridially active lactobacilli from semi-hard cheese. Czech Journal of Food Science 26, 324-332. https://doi.org/10.17221/115/2008-CJFS

57. Tungjaroenchai, W., White, C.H., Holmes, W.E., Drake, M.A. (2004) Influence of adjunct cultures on volatile free fatty acids in reduced-fat Edam cheeses. Journal of Dairy Science 87, 3224-3234 https://doi.org/10.3168/jds.S0022-0302(04)73458-X

58. Van Hoorde, K., Van Leuven, I., Dirinck, P., Heyndrickx, M., Coudijzer, K., Vandamme, P., Huys, G. (2010): Selection, application and monitoring of Lactobacillus paracasei strains as adjunct cultures in the production of Gouda-type cheeses. I International Journal of Food Microbiology 15, 144 (2), 226-235. https://doi.org/10.1016/j.ijfoodmicro.2010.05.007

59. Van Leuven, I., Van Caelenberg, T.V., Dirnick, P. (2008) Aroma characterisation of Gouda-type cheeses. International Dairy Journal 18(8), 790-800. https://doi.org/10.1016/j.idairyj.2008.01.001

60. Vargas-Bello-Pérez, E., Î̃iguez-González, G., FehrmannCartes, K., Toro-Mujica, P., Garnsworthy, P.C. (2015) Influence of fish oil alone or in combination with hydrogenated palm oil on sensory characteristics and fatty acid composition of bovine cheese. Animal Feed Science and Technology 205, 60-68. https://doi.org/10.1016/j.anifeedsci.2015.04.013

61. Voigt, D.D., Chevalier, F., Qian, M.C., Kelly, A.L. (2010): Effect of high-pressure treatment on microbiology, proteolysis, lipolysis and levels of flavour compounds in mature blue-veined cheese. Innovative Food Science and Emerging Technologies 11, 68-73. https://doi.org/10.1016/j.ifset.2009.10.009

62. Yu, L., Hammond, E.G. (2000): Production and characterization of a Swiss cheese-like product from modified vegetable oils. Journal of the American Oil Chemists' Society 77 (9), 917-924. https://doi.org/10.1007/s11746-000-0145-y

63. Zaręba, D., Obiedziński, M., Ziarno, M. (2008): Comparing the profile of volatile compounds in milk fermented and non-fermented by yoghurt bacteria and probiotic strains. Żywność Nauka Technologia Jakość 15 (3), 18-32. 